\title{
FRUCTOSE IN THE TREATMENT OF DIABETIC KETOSIS 1,2
}

\author{
BY J. H. DARRAGH, ${ }^{8}$ R. A. WOMERSLEY, AND W. H. MERONEY 4 \\ (From the Department of Internal Medicine, Yale University School of Medicine, New Haven, \\ Conn.)
}

(Submitted for publication June 22, 1953; accepted August 11, 1953)

It has long been hoped that a carbohydrate compound could be found which would be utilized effectively in diabetes mellitus without the aid of insulin. Many different hexoses and carbohydrate intermediaries have been tried. However, owing to enzymatic activity in the intestinal mucosa and liver, most of these are converted to glycogen and the net result, in most instances, is comparable to giving similar amounts of glucose (1). Of the hexoses other than glucose, fructose has shown the most promise. The metabolism of fructose differs significantly from that of glucose, despite close similarity in chemical structure. Glucose enters cells by phosphorylation to form glucose-6-phosphate, under the influence of glucokinase. Insulin is necessary to activate this reaction. Fructose enters cells by phosphorylation to form fructose phosphate, under the influence of fructokinase, which does not require activation by insulin (2). One of the blocks in carbohydrate metabolism in diabetes mellitus is the phosphorylation of glucose (3). Other enzyme systems, hexose isomerase and phosphatase, are intact, even in severe diabetes mellitus with ketosis. Fructose should, then, circumvent one of the blocks in carbohydrate metabolism in this disease.

Miller and others $(4,5,6)$ have shown that fructose, when administered intravenously, is removed from the blood as rapidly by the diabetic in the absence of insulin as by the normal subject. If fructose could be utilized by patients in diabetic ketosis, at a time when glucose utilization is reduced to a minimum, carbohydrate metabolism would be restored, with a resulting decrease in hepatic ketone body production, decreased ketonemia, and correc-

\footnotetext{
1 Presented at the Forty-fifth Annual Meeting of the American Society for Clinical Investigation, Atlantic City, N. J., May 4, 1953.

2 This work was aided by a research grant from the U. S. Public Health Service.

${ }^{3}$ Work done in part during the tenure of a U. S. Public Health Service Fellowship.

4 Major, Medical Corps, U. S. Army.
}

tion of the disturbance in acid-base equilibrium. Fructose might also serve as a convenient vehicle for the administration of water. The purpose of the following study was to determine whether the intravenous administration of fructose has any advantages over the similar use of glucose (7) in the treatment of diabetic ketosis.

\section{EXPERIMENTAL PROCEDURE AND METHODS}

Eleven studies have been carried out on five male and five female patients, ranging in age from 16 to 60 years. One patient was treated on two separate occasions. All had the usual clinical and chemical signs of diabetic ketosis. In seven studies there was severe, and in four mild, ketosis.

The studies were divided into two groups. In the first group of four patients, the effects of the intravenous injection of fructose 5 and glucose early in the course of treatment of patients with diabetic ketosis were determined. An initial sample of venous blood was obtained for measurement of electrolytes and blood glucose.

An intravenous infusion of 0.9 per cent $\mathrm{NaCl}$ was started and regular insulin was given subcutaneously. Twenty-five $\mathrm{Gm}$. of fructose as a 25 per cent solution were injected intravenously in 10 minutes. Samples of venous blood were obtained every 10 to 15 minutes for two hours after the administration of fructose and analyzed for glucose and fructose. Two of these patients received $25 \mathrm{Gm}$. of glucose intravenously as a 25 per cent solution in 10 minutes, one before and one after the administration of fructose. For comparison, $25 \mathrm{Gm}$. of fructose were given in a similar manner to two normal male subjects in the post-absorptive state.

In the second group of seven studies on six patients, larger amounts of fructose were used with insulin and electrolyte solutions in the treatment of diabetic ketosis. The fructose was given as an isotonic solution, 2.5 per cent fructose in 0.45 per cent $\mathrm{NaCl}$. This solution was made by mixing equal quantities of isotonic fructose and saline solutions. Insulin was started at the same time as the infusion in five of the seven studies. In order to determine the effect of fructose administration without insulin, two patients with mild ketosis did not receive insulin until after they had received $50 \mathrm{Gm}$. of fructose.

Three to nine liters of the fructose-hypotonic saline solution were infused. After the termination of these in-

5 The fructose used in these studies was supplied by E. R. Squibb and Sons. 
TABLE I

Analytical data, blood and serum, for patients with diabetic ketosis receiving 2.5 per cent fructose in 0.45 per cent NaCl

\begin{tabular}{|c|c|c|c|c|c|c|c|c|c|c|c|c|}
\hline \multirow[b]{2}{*}{$\begin{array}{l}\text { Study* } \\
\text { no. }\end{array}$} & Patient & \multirow[b]{2}{*}{ Wt. } & \multirow[b]{2}{*}{ Time } & \multicolumn{3}{|c|}{ Blood } & \multicolumn{6}{|c|}{ Serum } \\
\hline & Sex Age & & & $\begin{array}{l}\text { Glu- } \\
\text { cose }\end{array}$ & $\begin{array}{c}\text { Fruc- } \\
\text { tose }\end{array}$ & $\begin{array}{c}\text { Total } \\
\text { ketones }\end{array}$ & $\begin{array}{c}\text { Total } \\
\text { hexoseł }\end{array}$ & $\mathrm{Na}$ & $\mathbf{K}$ & $\mathrm{Cl}$ & $\mathrm{CO}_{2}$ & $\begin{array}{l}\text { Tot. } \\
\text { prot. }\end{array}$ \\
\hline 1 & 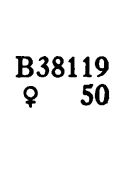 & $\begin{array}{c}K g . \\
50\end{array}$ & $\begin{array}{c}\text { Hrs. } \\
0.0 \dagger \\
2.7 \\
5.5 \\
12.88\end{array}$ & $\begin{array}{r}m g . / \\
100 \text { cc. } \\
488 \\
394 \\
263 \\
184\end{array}$ & $\begin{array}{c}m g . / \\
100 \text { cc. } \\
0 \\
55 \\
33 \\
0\end{array}$ & $\begin{array}{c}m M / \\
L . \\
18 \\
14 \\
5 \\
3\end{array}$ & $\begin{array}{c}m M / \\
L . \\
16 \\
10 \\
6\end{array}$ & $\begin{array}{c}m E q . / \\
L . \\
134 \\
126 \\
137\end{array}$ & $\begin{array}{c}m E q . / \\
L .6 \\
3.6 \\
\\
3.8 \\
3.9\end{array}$ & $\begin{array}{c}m E q . / \\
L . \\
102 \\
\\
110 \\
113\end{array}$ & $\begin{array}{c}m E q . / \\
L . / \\
5.3 \\
12.9 \\
16.5\end{array}$ & $\begin{array}{c}G m . / \\
100 c . \\
8.4 \\
6.2 \\
6.0\end{array}$ \\
\hline 2 & $\begin{array}{r}31037 \\
q^{3} 60\end{array}$ & 58 & $\begin{array}{l}0.0 \\
1.3 \dagger \\
2.1 \\
3.3 \\
4.0 \\
5.3 \\
16.0\end{array}$ & $\begin{array}{l}337 \\
300 \\
260 \\
244 \\
192 \\
214\end{array}$ & $\begin{array}{r}0 \\
41 \\
44 \\
60 \\
54 \\
0\end{array}$ & $\begin{array}{r}12 \\
10 \\
8 \\
6 \\
4 \\
2\end{array}$ & $\begin{array}{l}8 \\
7\end{array}$ & $\begin{array}{l}123 \\
140\end{array}$ & $\begin{array}{l}3.7 \\
3.8\end{array}$ & $\begin{array}{l}109 \\
108\end{array}$ & $\begin{array}{l}14.6 \\
15.9\end{array}$ & 7.7 \\
\hline 3 & $\begin{array}{rr}\text { B28609 } \\
\sigma^{77} & 16\end{array}$ & 44 & $\begin{array}{c}0.0 \\
0.3 \dagger \\
2.3 \\
4.9 \\
14.8\end{array}$ & $\begin{array}{l}443 \\
469 \\
285 \\
176\end{array}$ & $\begin{array}{r}0 \\
31 \\
36 \\
0\end{array}$ & $\begin{array}{r}18 \\
16 \\
12 \\
3\end{array}$ & 11 & $\begin{array}{l}139 \\
140\end{array}$ & $\begin{array}{l}3.2 \\
2.9\end{array}$ & $\begin{array}{l}111 \\
103\end{array}$ & $\begin{array}{r}8.3 \\
17.2\end{array}$ & $\begin{array}{l}6.8 \\
5.5\end{array}$ \\
\hline 4 & $\begin{array}{r}\text { A66992 } \\
\& \quad 47\end{array}$ & 50 & $\begin{array}{r}0.0 \dagger \\
7.0 \\
21.4\end{array}$ & $\begin{array}{l}392 \\
208 \\
113\end{array}$ & $\begin{array}{l}0 \\
7 \\
0\end{array}$ & $\begin{array}{r}16 \\
4 \\
2\end{array}$ & $\begin{array}{r}13 \\
4\end{array}$ & $\begin{array}{l}135 \\
140\end{array}$ & $\begin{array}{l}4.6 \\
4.3\end{array}$ & 98 & $\begin{array}{l}13.6 \\
22.3\end{array}$ & $\begin{array}{l}7.3 \\
6.1\end{array}$ \\
\hline 5 & $\begin{array}{r}\text { B55316 } \\
\text { \& } \quad 58\end{array}$ & 50 & $\begin{array}{c}0.0 \\
1.5 \dagger \\
3.5 \\
11.0\end{array}$ & $\begin{array}{l}286 \\
334 \\
212 \\
111\end{array}$ & $\begin{array}{r}0 \\
32 \\
30 \\
0\end{array}$ & $\begin{array}{r}15 \\
13 \\
10 \\
5\end{array}$ & $\begin{array}{l}9 \\
8 \\
4\end{array}$ & $\begin{array}{l}129 \\
118 \\
135\end{array}$ & $\begin{array}{l}3.6 \\
2.8 \\
3.5\end{array}$ & $\begin{array}{r}100 \\
101 \\
98\end{array}$ & 22.0 & $\begin{array}{l}6.4 \\
5.4 \\
5.6\end{array}$ \\
\hline $6 a$ & $\begin{array}{r}\text { B30072 } \\
\& \quad 32\end{array}$ & 57 & $\begin{array}{c}0.0 \\
5.0 \dagger \\
16.8\end{array}$ & $\begin{array}{l}449 \\
508 \\
147\end{array}$ & $\begin{array}{r}0 \\
20 \\
0\end{array}$ & $\begin{array}{r}11 \\
9 \\
2\end{array}$ & $\begin{array}{r}15 \\
5\end{array}$ & $\begin{array}{l}130 \\
136\end{array}$ & $\begin{array}{l}4.8 \\
4.1\end{array}$ & $\begin{array}{r}93 \\
104\end{array}$ & $\begin{array}{l}12.9 \\
19.4\end{array}$ & 5.2 \\
\hline $6 b$ & 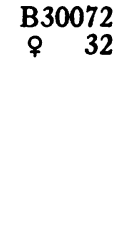 & 56 & $\begin{array}{r}0.0 \dagger \\
3.3 \\
5.1 \\
6.0 \\
7.8 \\
9.6 \\
11.0 \\
18.3\end{array}$ & $\begin{array}{r}1780 \\
1375 \\
1045 \\
854 \\
561 \\
383 \\
286 \\
56\end{array}$ & $\begin{array}{l}0 \\
35 \\
45 \\
49 \\
51 \\
26 \\
27 \\
12\end{array}$ & $\begin{array}{r}27 \\
22 \\
17 \\
15 \\
11 \\
8 \\
6 \\
5\end{array}$ & $\begin{array}{r}59 \\
30 \\
13 \\
2\end{array}$ & $\begin{array}{l}112 \\
124\end{array}$ & $\begin{array}{l}8.4 \\
3.4\end{array}$ & $\begin{array}{l}71 \\
92\end{array}$ & $\begin{array}{r}4.4 \\
12.2 \\
19.0\end{array}$ & $\begin{array}{l}6.5 \\
6.2\end{array}$ \\
\hline
\end{tabular}

* Study No. 1. Infusion 6.0 liters $2.5 \%$ fructose in $0.45 \% \mathrm{NaCl} . \quad 0.2-6.1 \mathrm{Hrs}$.

2. Infusion 4.8 liters $2.5 \%$ fructose in $0.45 \% \mathrm{NaCl}$. $1.3-5.3 \mathrm{Hrs}$.

3. Infusion 4.0 liters $2.5 \%$ fructose in $0.45 \% \mathrm{NaCl}$. $0.3-4.8 \mathrm{Hrs}$.

4. Infusion 3.0 liters $2.5 \%$ fructose in $0.45 \% \mathrm{NaCl}$. $0.5-7.0 \mathrm{Hrs}$.

5. Infusion 4.0 liters $2.5 \%$ fructose in $0.45 \% \mathrm{NaCl}$. $0.0-3.6 \mathrm{Hrs}$.

6a. Infusion 5.0 liters $2.5 \%$ fructose in $0.45 \% \mathrm{NaCl}$. $0.0-15.8 \mathrm{Hrs}$.

6b. Infusion 9.0 liters $2.5 \%$ fructose in $0.45 \% \mathrm{NaCl}$. $0.8-18.3 \mathrm{Hrs}$.

† Insulin therapy started.

$\ddagger$ The osmotic contribution of the serum total hexose $(\mathrm{mM} / \mathrm{L})=.\frac{\text { Blood total hexose }(\mathrm{mg} . / 100 \mathrm{cc} .) \times 10}{360 \times 0.85}$.

$\$$ Italics indicate observations after the infusion of fructose hypotonic saline solution.

fusions, the patients received further infusions of saline, glucose, fructose, and oral fluids until they could be maintained on oral intake completely. Potassium chloride was added to the fructose-hypotonic saline solution in five of the seven studies. Four patients received oral as well as parenteral fluids during the infusion. The electrolyte and carbohydrate content of these fluids, as determined from standard food tables (8), are included in the balance data.

Samples of venous blood were obtained before and at intervals during the infusion of the fructose-hypotonic saline solution. A blood sample was obtained at the end of the infusion in all but one study. In the first six studies, a sample of venous blood was obtained several hours after the termination of the fructose-hypotonic saline solution. Urine was collected from the start of treatment. An indwelling catheter was used once; the remainder of the urine specimens were voided. The balance periods outlined in Tables II and III began at the time of the initial 
TABLE II

Intake and excretion in urine for patients with diabetic ketosis receiving infusion of 2.5 per cent fructose in 0.45 per cent NaCl

\begin{tabular}{|c|c|c|c|c|c|c|c|c|c|c|c|c|c|c|c|c|}
\hline \multirow[b]{2}{*}{$\begin{array}{c}\text { Study } \\
\text { no. }\end{array}$} & \multirow[b]{2}{*}{ Duration } & \multicolumn{7}{|c|}{ Intake } & \multicolumn{8}{|c|}{ Excretion in urine } \\
\hline & & Insulin & $\mathrm{H}_{2} \mathrm{O}$ & $\mathrm{Na}$ & $\mathbf{K}$ & $\mathrm{Cl}$ & $\underset{\text { sugar* }}{\text { Oral }}$ & $\begin{array}{l}\text { I.V. } \\
\text { fructose }\end{array}$ & $\mathrm{H}_{2} \mathrm{O}$ & $\mathrm{Na}$ & $\mathbf{K}$ & $\mathrm{NH}_{\mathbf{2}}$ & $\mathrm{Cl}$ & $\begin{array}{c}\text { Total } \\
\text { ketones }\end{array}$ & $\begin{array}{l}\text { Glu- } \\
\text { cose }\end{array}$ & $\begin{array}{c}\text { Fruc- } \\
\text { tose }\end{array}$ \\
\hline $\begin{array}{l}1 \\
2 \\
3 \\
4 \\
5 \\
6 a \\
6 b\end{array}$ & $\begin{array}{l}\text { Hours } \\
0-5.5 \\
0-5.3 \\
0-4.9 \\
0-7.0 \\
0-3.5 \\
0-13.0 \\
0-6.0 \\
6.0-9.6 \\
9.6-18.3\end{array}$ & $\begin{array}{r}U \text { uits } \\
200 \\
88 \\
150 \\
100 \\
50 \\
125 \\
480 \\
100 \\
0\end{array}$ & $\begin{array}{c}\text { Liters } \\
5.2 \\
5.2 \\
4.9 \\
3.2 \\
4.0 \\
5.0 \\
3.9 \\
2.7 \\
2.4\end{array}$ & $\begin{array}{l}m E q . \\
398 \\
370 \\
393 \\
231 \\
308 \\
385 \\
299 \\
212 \\
183\end{array}$ & $\begin{array}{c}m E q . \\
47 \\
80 \\
90 \\
5 \\
0 \\
40 \\
0 \\
52 \\
28\end{array}$ & $\begin{array}{l}m E q . \\
445 \\
450 \\
473 \\
231 \\
308 \\
425 \\
299 \\
264 \\
211\end{array}$ & $\begin{array}{r}G m . \\
0 \\
0 \\
22 \\
11 \\
0 \\
0 \\
0 \\
0 \\
0\end{array}$ & $\begin{array}{r}\text { Gm. } \\
129 \\
120 \\
100 \\
75 \\
100 \\
125 \\
97 \\
69 \\
59\end{array}$ & $\begin{array}{c}\text { Liters } \\
1.3 \\
1.0 \\
1.2 \\
1.3 \\
0.3 \\
2.5 \\
1.6 \\
0.8 \\
0.6\end{array}$ & $\begin{array}{l}m E q . \\
62 \\
16 \\
59 \\
63 \\
18 \\
98 \\
21 \\
13 \\
8\end{array}$ & $\begin{array}{c}m E q . \\
28 \\
17 \\
41 \\
45 \\
6 \\
62 \\
15 \\
7 \\
9\end{array}$ & $\begin{array}{l}m E q . \\
22 \\
39 \\
31 \\
\\
74 \\
26 \\
11 \\
18\end{array}$ & $\begin{array}{l}m E q . \\
45 \\
24 \\
25 \\
26 \\
9 \\
53 \\
14 \\
9 \\
13\end{array}$ & $\begin{array}{r}m M \\
58 \\
27 \\
84 \\
71 \\
29 \\
128 \\
39 \\
18 \\
12\end{array}$ & $\begin{array}{r}G m . \\
44.8 \\
7.3 \\
55.3 \\
47.8 \\
7.6 \\
77.1 \\
91.7 \\
28.5 \\
13.0\end{array}$ & $\begin{array}{l}G m . \\
5.3 \\
2.9 \\
3.6 \\
4.9 \\
2.9 \\
2.6 \\
2.4 \\
2.2 \\
1.9\end{array}$ \\
\hline
\end{tabular}

* Carbohydrate drinks, chiefly sucrose.

blood sample, and terminated at the end of the infusion of the fructose-hypotonic saline solution. Some of the urine collection periods did not coincide with the beginning and end of the balance periods. Appropriate corrections have been made to include only the proper fraction of the total urine.

Serum was analyzed for sodium, potassium, chloride, carbon dioxide content, and total protein; blood for total hexose, fructose, and total ketones; urine for sodium, potassium, ammonia, chloride, total ketones, total hexose, and fructose. Total hexose of whole blood was determined by the method of Nelson (9), using zinc filtrates (10), and in the urine by the method of Somogyi (11). Fructose was determined in zinc filtrates of whole blood, and in urine by the method of Schreiner (12) in the first group of studies, and by the method of Kendrick (13) in the second group. Glucose was computed as the difference between total hexose and fructose. Total ketones in blood and urine were determined by Michaels' modification of the method of Greenberg and Lester (14). Other methods were identical with those previously reported from this laboratory $(15,16,17)$.

Balance data were calculated by methods previously reported from this department $(18,19)$, and by Darrow (20). Cellular transfers of potassium were not corrected for the balance of cellular nitrogen. In calculating the water balance, an allowance of $1 \mathrm{cc}$. per minute was made for insensible loss. No adjustment was made for the water of oxidation. No corrections have been made for the small amounts of electrolytes lost in the removal of blood

TABLE III

External, extracellular and intracellular balances for patients with diabetic ketosis receiving infusions of 2.5 per cent fructose in 0.45 per cent $\mathrm{NaCl}$

\begin{tabular}{|c|c|c|c|c|c|c|c|c|c|c|c|c|c|}
\hline \multirow{2}{*}{$\begin{array}{c}\text { Study } \\
\text { no. }\end{array}$} & \multirow[b]{2}{*}{ Time } & \multirow{2}{*}{$\begin{array}{l}\text { Extra- } \\
\text { cellular } \\
\text { volume* }\end{array}$} & \multicolumn{5}{|c|}{ External balance } & \multicolumn{3}{|c|}{ Extracellular balance } & \multicolumn{3}{|c|}{ Intracellular balance } \\
\hline & & & $\mathrm{H}_{2} \mathrm{O}$ & $\mathrm{Na}$ & $\mathbf{K}$ & $\mathrm{Cl}$ & Sugar & $\mathrm{H}_{2} \mathrm{O}$ & $\mathrm{Na}$ & $\mathbf{K}$ & $\mathrm{H}_{2} \mathrm{O}$ & $\mathrm{Na}$ & $\mathbf{K}$ \\
\hline 1 & $\begin{array}{c}\text { Hours } \\
0 \\
5.5\end{array}$ & $\begin{array}{c}\text { Liters } \\
7.3 \\
(10.0)\end{array}$ & $\begin{array}{l}\text { Liters } \\
+3.5\end{array}$ & $\begin{array}{l}m E q . \\
+336\end{array}$ & $\begin{array}{l}m E q . \\
+19\end{array}$ & $\begin{array}{l}m E q . \\
+400\end{array}$ & $\begin{array}{r}G m . \\
+\quad 79\end{array}$ & $\begin{array}{l}\text { Liters } \\
+2.7\end{array}$ & $\begin{array}{l}m E q . \\
+265\end{array}$ & $\begin{array}{l}m E q . \\
+19\end{array}$ & $\begin{array}{l}\text { Liters } \\
+0.8\end{array}$ & $\begin{array}{l}m E q . \\
+71\end{array}$ & $\begin{array}{l}m E q . \\
+7\end{array}$ \\
\hline 2 & $\begin{array}{l}0 \\
5.3\end{array}$ & $\begin{array}{c}8.4 \\
(11.6)\end{array}$ & +3.9 & +354 & +63 & +426 & +110 & +3.2 & +357 & +12 & +0.7 & -3 & +51 \\
\hline 3 & $\begin{array}{l}0 \\
4.9\end{array}$ & $\begin{array}{c}5.9 \\
(8.7)\end{array}$ & +3.4 & +334 & +49 & +448 & +63 & +2.9 & +375 & +8 & +0.5 & -41 & +41 \\
\hline 4 & 7.0 & & +1.5 & +168 & -40 & +203 & +33 & & & & & & \\
\hline 5 & $\begin{array}{l}0 \\
3.5\end{array}$ & $\begin{array}{l}(9.7) \\
12.3\end{array}$ & +3.5 & +290 & -6 & +299 & +90 & +2.6 & +185 & -1 & +0.9 & +105 & -5 \\
\hline $6 a$ & 13.0 & & +1.7 & +287 & +22 & +372 & +45 & & & & & & \\
\hline $6 \mathrm{~b}$ & $\begin{array}{c}0 \\
6.0 \\
9.6 \\
18.3\end{array}$ & $\begin{array}{r}7.4 \\
8.5 \\
9.9 \\
(11.2)\end{array}$ & $\begin{array}{l}+2.0 \\
+1.7 \\
+1.2\end{array}$ & $\begin{array}{l}+278 \\
+199 \\
+175\end{array}$ & $\begin{array}{l}-15 \\
+45 \\
+19\end{array}$ & $\begin{array}{l}+285 \\
+255 \\
+198\end{array}$ & $\begin{array}{l}+\quad 3 \\
+38 \\
+44\end{array}$ & $\begin{array}{l}+1.1 \\
+1.4 \\
+1.3\end{array}$ & $\begin{array}{l}+204 \\
+230 \\
+180\end{array}$ & $\begin{array}{r}-35 \\
+7 \\
+5\end{array}$ & $\begin{array}{l}+0.9 \\
+0.3 \\
-0.1\end{array}$ & $\begin{array}{l}+74 \\
\pm \quad 31 \\
-\quad 5\end{array}$ & $\begin{array}{l}+20 \\
+38 \\
+14\end{array}$ \\
\hline
\end{tabular}

* Calculated from changes in chloride balance, forward or backward, from an assumed extracellular volume (designated by parentheses) of 20 per cent of body weight. 
samples, nor in the sweat. Owing to the brevity of the balance periods, and the large transfers involved, the errors introduced by these assumptions are negligible.

\section{RESULTS}

\section{A. Intravenous fructose and glucose (Figures 1 and 2)}

The effects of the intravenous injection of fructose in four patients with severe diabetic ketosis, and in two normal subjects, are illustrated in Figure 1. The fructose disappeared from the blood at comparable rates in both the patients with diabetic ketosis and the normal subjects. The increase in blood glucose was greater in patients with diabetic ketosis than in normal subjects. In Figure 2 the effects of intravenous fructose and glucose in two patients with diabetic ketosis receiving insulin and intravenous saline are compared. In both patients blood glucose increased considerably after the infusion of glucose, but decreased after the infusion of fructose. The total hexose (glucose plus fructose) of the blood rose much less after the fructose than after the glucose infusion.

B. Patients with diabetic ketosis receiving 2.5 per cent fructose in 0.45 per cent $\mathrm{NaCl}$ (Tables I to $I I I)$

The initial blood glucose varied from 286 to $1780 \mathrm{mg}$. per $100 \mathrm{cc}$. In four studies (Nos. 1, 2,
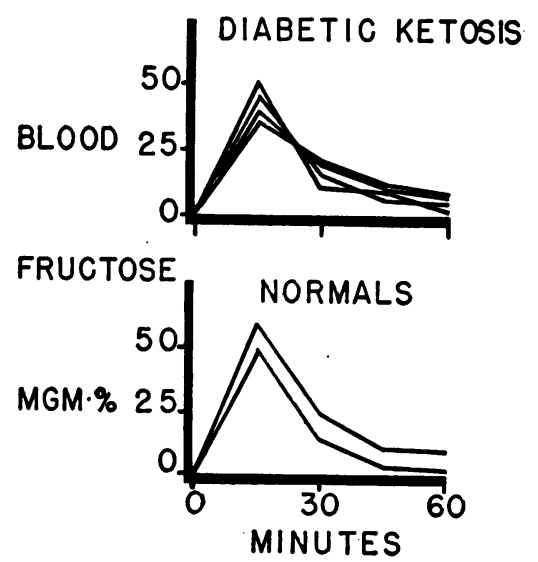

Fig. 1. The Effects of Intravenous Injection of Fructose in Four Patients with Severe Diabetic Ketosis and Two Normal Subjects

100 cc. of 25 per cent fructose solution were injected intravenously from 0 to 10 minutes. In the diabetic patients, treatment with regular insulin and intravenous saline had been started prior to 0 minutes.

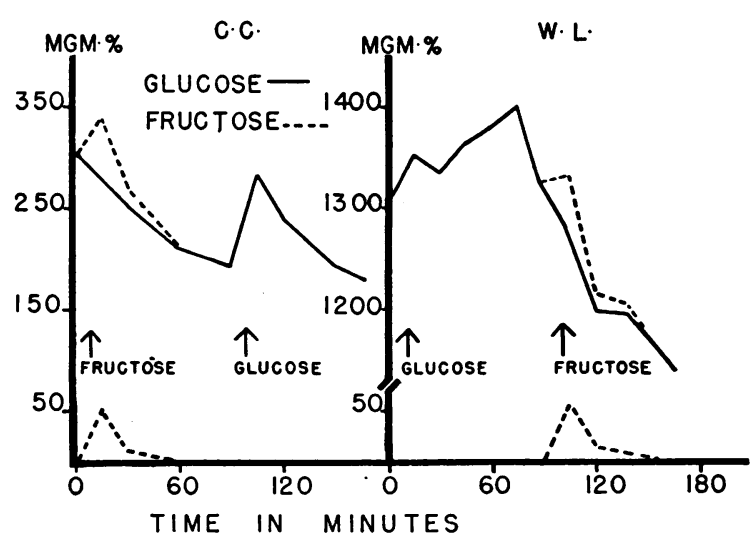

Fig. 2. The Effects of Intravenous Injection of Fructose and Glucose in Two Patients with Severe Diabetic Ketosis

Blood glucose is illustrated by solid lines; blood fructose by dotted lines. Blood fructose plus blood glucose equals total hexose. $100 \mathrm{cc}$. of a 25 per cent solution of fructose or glucose were injected intravenously in $10 \mathrm{~min}$ utes at the times indicated.

$4,6 \mathrm{~b}$.) there was a progressive fall in blood glucose in spite of the administration of 75 to $225 \mathrm{Gm}$. of fructose. In one study (No. 3) there was an initial rise in blood glucose when $22 \mathrm{Gm}$. of carbohydrate ${ }^{6}$ were given orally as well as intravenous fructose, and then a gradual fall in blood glucose. Although fructose was infused at rates up to 25 $\mathrm{Gm}$. per hour, the highest concentration of fructose in the blood was $60 \mathrm{mg}$. per $100 \mathrm{cc}$.

In two studies (Nos. 5, 6a) the patients received $50 \mathrm{Gm}$. of fructose before receiving insulin. Blood glucose increased during this period, but blood fructose remained low even without insulin. When insulin was added with the fructose, the blood glucose decreased.

Only a small part of the fructose was excreted in the urine ( 2 to 6 per cent). In most of the studies (Nos. 2 and 5 are the exceptions), much larger quantities of glucose than fructose appeared in the urine. The rate of excretion of glucose varied with the blood glucose and the urine flow, and was independent of the rate of fructose administration.

In every patient there was a steady and rapid fall in the total ketones in the blood. The decrease was greater than that which could be attributed to dilution of the body fluids by the infusion of the fructose-hypotonic saline solution. In two studies

\footnotetext{
${ }^{6}$ Chiefly sucrose.
} 
(Nos. 5, 6a) the blood ketones decreased both before and after the administration of insulin. The carbon dioxide of the serum was depressed about $1 \mathrm{mEq}$. per L. for each millimol of ketone bodies, as would be expected from theoretical considerations.

In three studies the initial concentration of sodium in the serum was in the normal range (134 to $144 \mathrm{mEq}$. per L.) but in the remaining four studies it was below normal. However, these values must be evaluated in terms of the other constituents of the body fluids. The tonicity of the body fluids may be defined as the concentration of those substances which exert an effective osmotic pressure because they are restrained from penetrating cell membranes and therefore can alter the distribution of water between the intracellular and extracellular phases. Under ordinary circumstances extracellular tonicity is almost completely determined by the concentration of sodium salts. Glucose does not enter cells readily, and therefore exerts an effective osmotic pressure. As demonstrated by Seldin and Tarail (21), hyperglycemia contributes significantly to the tonicity of the extracellular fluids. In these studies total hexose of whole blood was measured. The total hexose concentration in serum is about 15 per cent higher than in whole blood due to the distribution of water between cells and serum. In Table I the concentration of total hexose in serum has been expressed in $\mathrm{mM}$ per $\mathrm{L} . \div 2$, so that tonicity of the serum can be estimated from $2 \times$ (total hexose plus sodium). The tonicity of the serum was elevated in four of the studies before treatment (Nos. $1,3,4,6 \mathrm{~b})$, and normal in the remaining three (Nos. 2, 5, 6a). Hypertonicity was most marked in the last study (No. 6b) when the initial serum sodium was $112 \mathrm{mEq}$. per L. and the blood glucose $1780 \mathrm{mg}$. per $100 \mathrm{cc}$.

During treatment sodium was infused at a concentration of $77 \mathrm{mEq}$. per L. In five studies the serum sodium was determined before and after the infusion. In one (No. $6 \mathrm{~b}$ ) the serum sodium increased, in another (No. 3) it did not change, and in three studies it decreased (Nos. 1, 2, 4). In the latter three instances the serum sodium had returned to the normal range by the following morning (Table I-italics). In every instance the serum chloride increased during the infusion of the fructose-hypotonic saline solution.
The initial serum potassium was above normal in only one patient (No. $6 \mathrm{~b}$ ), but fell rapidly with rehydration and acceleration of carbohydrate metabolism. Potassium chloride $(7,22,24)$ was administered in five of the studies to prevent the development of hypokalemia (Table II). The urine was always hypotonic with respect to electrolytes (Table II). In every instance there was a significant loss of potassium in the urine, generally less than that of sodium and ammonia. Excretion of chloride was low initially, when there was a marked ketonuria, but increased rapidly with the decrease in the rate of excretion of ketones.

In every instance, a large positive balance of water, sodium, and chloride was achieved during the infusion of the fructose-hypotonic saline solution. The decrease in the concentration of proteins in the serum during the studies reflects correction of the dehydration. In six of the seven studies, sodium chloride was retained as a hypotonic solution (No. $6 \mathrm{a}$ is the exception). In the five studies in which the cellular balances have been calculated (Table III), the retained water was distributed chiefly in the extracellular compartment. In each instance there was a significant increase in intracellular water. When potassium chloride was added to the fructose-hypotonic saline solution (Table II), a positive balance of potassium was achieved. With one exception (No. 1), the potassium was distributed chiefly in the intracellular compartment.

\section{DISCUSSION}

The derangements of body water and electrolytes in severe diabetic ketosis have been reviewed by several authors $(7,21,23-25)$. As a result of hyperglycemia and glycosuria, hyperventilation, and the vomiting which frequently occurs in diabetic ketoacidosis, there is usually a loss of large quantities of intracellular and extracellular water and electrolytes. In most instances these substances are lost in proportions less than their concentration in the body fluids, so that the net result is hypertonicity of the body fluids and cellular dehydration. Seldin and Tarail (21) have demonstrated that the hypertonicity is not apparent if only the concentration of sodium chloride in the serum is considered. Glucose does not enter cells readily and thus contributes to the effective osmotic pressure of the extracellular fluid, which must be 
estimated from the concentration of sodium and its salts plus the osmotic contribution of glucose. In the treatment of diabetic ketosis, deficits of water and electrolytes must be replaced. Water is needed in excess of that in isotonic solutions to correct hypertonicity and cellular dehydration, as well as the provision for urine and insensible loss which is increased with the hyperpnea of diabetic ketosis. Infusion of hypertonic electrolyte or glucose solutions will increase the hypertonicity and cellular dehydration. Danowski and his associates (24) found that the infusion of large volumes of isotonic saline can prolong the hypertonicity. For these reasons Butler (25), Seldin and Tarail (21), and Peters (7), have recommended hypotonic electrolyte solutions in diabetic acidosis. There are objections to the rapid infusion of large volumes of hypotonic electrolyte solutions. Hence, glucose has been used as a vehicle for the water so that an isotonic solution could be administered, either by giving isotonic glucose ( 5 per cent) and isotonic saline separately, or mixed together in equal quantities, 2.5 per cent glucose in 0.45 per cent saline. However, in severe diabetic ketosis, when carbohydrate metabolism is reduced to a minimum, glucose is not an ideal vehicle for water. $U p$ to the present, it has been recommended because none better was available. Glucose administered early in the course of treatment of diabetic ketosis either increases the blood glucose or delays its return to normal $(21,26)$. The data presented here show that fructose disappears from the blood, even in severe diabetic ketosis, and that the blood total hexose decreases if adequate amounts of insulin are given. Hence, fructose is a better vehicle than glucose for the administration of the excess water required in the correction of the dehydration associated with diabetic ketosis. Other investigators have arrived at the same conclusion $(27,28)$.

The need for excess water in the treatment of diabetic ketosis is illustrated best in the last study (No. 6b, Tables I-III). This patient received in 18.3 hours 9 liters of water, containing $693 \mathrm{mEq}$. of sodium and $225 \mathrm{Gm}$. of fructose. Of the 9 liters, 3.8 liters were retained in the extracellular compartment together with $614 \mathrm{mEq}$. of sodium (162 $\mathrm{mEq}$. per liter). The remaining 6.2 liters were utilized as hypotonic solutions : intracellular water, 1.1 liters with $38 \mathrm{mEq}$. of sodium; urine, 3 liters with $42 \mathrm{mEq}$. of sodium ; and 1.1 liters for insensi- ble loss (total electrolyte content less than $10 \mathrm{mEq}$. per liter).

Fructose circumvents one of the blocks in carbohydrate metabolism in diabetes mellitus $(2,3)$. It was hoped that fructose would prove to be more antiketogenic than glucose. In these patients treated with insulin and fructose, there was a rapid and steady decrease in blood ketones. When fructose was given without insulin to two patients with mild ketosis (Nos. 5, 6a, Table I), there was a slight decrease in blood ketones, but fructose did not appear to be more antiketogenic than glucose. Rosecan and Daughaday (29) have compared the treatment of diabetic ketosis with insulin and saline, and insulin, saline, and glucose or fructose. They found a more rapid disappearance of the ketosis with insulin plus carbohydrate, but found that fructose was no more antiketogenic than glucose.

Fructose administered intravenously in diabetic ketosis disappears rapidly from the blood. Only small amounts of fructose are excreted in the urine. Miller and his associates $(4,30)$ have demonstrated that: 1) There is a large hepatic uptake of fructose in diabetic patients deprived of insulin; 2) some of the fructose is converted to glucose by the liver; 3 ) in severe diabetic ketosis as much as 22 per cent of intravenously administered fructose can be utilized even in the absence of insulin $(31)$; 4) in severe diabetes without insulin, $\mathrm{C}^{14}$-labelled fructose is oxidized to $\mathrm{C}^{14} \mathrm{O}_{2}$ at the same rate as in normal subjects (31). The elevation of blood glucose which follows the intravenous administration of fructose is variable. It is greater in patients with diabetes than in normal subjects, and in diabetics it is less with insulin than without insulin. Even in mild diabetic ketosis (Nos. 5, 6a, Table I) fructose without insulin produced an increase in blood glucose.

In the choice of a carbohydrate compound for use in the early treatment of diabetic acidosis, fructose has advantages over glucose. Part of the fructose is utilized when glucose would be excreted quantitatively in the urine. Fructose administered intravenously is removed rapidly from the blood, releasing the water.

There is not an elevation of the blood glucose when adequate amounts of insulin are given. We have started the parenteral fluid therapy of diabetic ketosis with fructose as a 2.5 per cent solu- 
tion in 0.45 per cent $\mathrm{NaCl}$ so as to administer an isotonic solution early in the course of treatment when there is usually hypertonicity of the body fluids, with some salt, but chiefly water depletion. In a patient with prolonged and severe diabetic acidosis with shock, the blood volume should also be expanded with blood, plasma, or colloid solutions. Once the blood sugar has begun to fall, owing to the acceleration of carbohydrate metabolism, and hypertonicity has been corrected, more concentrated solutions should be used, such as 5 per cent or 10 per cent fructose or glucose, in order to prevent the development of hypoglycemia $(7,21)$.

\section{CONCLUSIONS}

1. Fructose disappears rapidly from the blood in patients with diabetic ketosis, with or without insulin, and at the same rate as in normal subjects.

2. By using fructose instead of glucose, together with adequate amounts of insulin, carbohydrate can be administered early in the course of treatment of diabetic ketosis without increasing the effective osmotic pressure of the extracellular fluid.

3. The dehydration associated with diabetic ketosis can be corrected rapidly by infusing a hypotonic electrolyte solution made up to isotonicity with fructose. Intracellular water is increased early in the course of treatment.

\section{ACKNOWLEDGMENTS}

The authors would like to thank Dr. J. P. Peters and Dr. M. Miller for their help in the preparation of this manuscript.

\section{REFERENCES}

1. Peters, J. P., and Van Slyke, D. D., Quantitative Clinical Chemistry, ed. 2, Baltimore, The Williams \& Wilkins Co., 1946, vol. 1, p. 140.

2. Cori, G. T., Ochoa, S., Slein, M. W., and Cori, C. F., The metabolism of fructose in liver. Isolation of fructose-I-phosphate and inorganic pyrophosphate. Biochim. et Biophys. Acta, 1951, 7, 304.

3. Chernick, S. S., and Chaikoff, I. L., Two blocks in carbohydrate utilization in the liver of the diabetic rat. J. Biol. Chem., 1951, 188, 389.

4. Miller, M., Drucker, W. R., Owens, J. E., Craig, J. W., and Woodward, H., Jr., Metabolism of intravenous fructose and glucose in normal and diabetic subjects. J. Clin. Invest., 1952, 31, 115.

5. Smith, L. H., Jr., Ettinger, R. H., and Seligson, D., A comparison of the metabolism of fructose and glucose in hepatic disease and diabetes mellitus. J. Clin. Invest., 1953, 32, 273.

6. Weichselbaum, T. E., and Daughaday, W. H., The rate of assimilation of fructose following the intravenous administration to patients with diabetic acidosis and total pancreatectomy. J. Lab. \& Clin. Med., 1951, 38, 958.

7. Peters, J. P., Diabetic acidosis. Metabolism, 1952, 1, 223.

8. McCance, R. A., and Widdowson, E. M., The Chemical Composition of Foods, Brooklyn, Chemical Publishing Co., 1947.

9. Nelson, N., A photometric adaptation of the Somogyi method for the determination of glucose. J. Biol. Chem., 1944, 153, 375.

10. Somogyi, M., A method for the preparation of blood filtrates for the determination of sugar. J. Biol. Chem., 1930, 86, 655.

11. Somogyi, M., Notes on sugar determination. J. Biol. Chem., 1952, 195, 19.

12. Schreiner, G. E., Determination of inulin by means of resorcinol. Proc. Soc. Exper. Biol. \& Med., 1950, 74, 117.

13. Kendrick, A. B., Determination of fructose in presence of glucose in blood and urine by use of diphenylamine. Federation Proc., 1952, 11, 239.

14. Michaels, G. D., Margen, S., Liebert, G., and Kinsell, L. W., Studies in fat metabolism. I. The colorimetric determination of ketone bodies in biological fluids. J. Clin. Invest., 1951, 30, 1483.

15. Hald, P. M., Determinations with Flame Photometer, Methods in Medical Research, The Yearbook Publishers, Inc., 1951, vol. 4, p. 79.

16. Elkinton, J. R., and Taffel, M., Prolonged water deprivation in the dog. J. Clin. Invest., 1942, 21, 787.

17. Conway, E. J., Microdiffusion Analysis and Volumetric Error, London, C. Lockwood, 1947, p. 357.

18. Elkinton, J. R., and Winkler, A. W., Transfers of intracellular potassium in experimental dehydration. J. Clin. Invest., 1944, 23, 93.

19. Elkinton, J. R., Winkler, A. W., and Danowski, T. S., Transfers of cell sodium and potassium in experimental and clinical conditions. J. Clin. Invest., 1948, 27, 74.

20. Darrow, D. C., The retention of electrolyte during the recovery from severe dehydration due to diarrhea. J. Pediat., 1946, 28, 515.

21. Seldin, D. W., and Tarail, R., The metabolism of glucose and electrolytes in diabetic acidosis. J. Clin. Invest., 1950, 29, 552.

22. Dyer, W. W., Potassium: Metabolic Aspects (Diabetes) in Advances in Medicine and Surgery, Philadelphia, W. B. Saunders Co., 1952, p. 94.

23. Atchley, D. W., Loeb, R. F., Richards, D. W., Jr., Benedict, E. M., and Driscoll, M. E., On diabetic acidosis. A detailed study of electrolyte balances following the withdrawal and reestablishment of insulin therapy. J. Clin. Invest., 1933, 12, 297. 
24. Danowski, T. S., Peters, J. H., Rathbun, J. C., Quashnock, J. M., and Grenman, L., Studies in diabetic acidosis and coma, with particular emphasis on the retention of administered potassium. J. Clin. Invest., $1949,28,1$.

25. Butler, A. M., Diabetic coma. New England J. Med., 1950, 243, 648.

26. Franks, M., Berris, R. F., Kaplan, N. O., and Myers, G. B., Metabolic studies in diabetic acidosis. I. The effect of the early administration of dextrose. Arch. Int. Med., 1947, 80, 739.

27. Dolger, H., Kupfer, S., Bookman, J. J., and Carr, J., Intravenous fructose in diabetes mellitus: advantages over glucose in the treatment of diabetic emergencies. J. Clin. Invest., 1953, 32, 562.

28. Miller, M., Murphy, J. R., Craig, J. W., and Woodward, H., Jr., Studies in experimental diabetic acidosis : comparison of the effect of fructose and glucose in the initial hours of treatment. Presented at the 13th Annual Meeting, Am. Diabetes A., New York, N. Y., May 30, 1953.

29. Rosecan, M., and Daughaday, W. H., A comparison of insulin treatment with and without added carbohydrate in human diabetic ketosis. J. Clin. Invest., 1953, 32, 599.

30. Craig, J. W., Drucker, W. R., Miller, M., Owens, J. E., Woodward, H., Jr., Brofman, B., and Pritchard, W. H., Metabolism of fructose by the liver of diabetic and non-diabetic subjects. Proc. Soc. Exper. Biol. \& Med., 1951, 78, 698.

31. Miller, M., Craig, J. W., Woodward, H., Jr., Owens, J. E., Drucker, W., and Murphy, J., The metabolism of fructose in diabetic subjects. Presented at the 12th Annual Meeting, Am. Diabetes A., Chicago, Ill., June 7-8, 1952. 